\section{Changes in the Radiation Toxicity of Human Lymphoblastic T-cell Line (Jurkat) by a Common Pesticide: Diazinon}

\author{
Ghasemi Sh. ${ }^{1 \odot}$, Shabestani Monfared A. ${ }^{2,3 *}{ }^{\circledR}$, Zabihi E.4, \\ Khoshbin Khoshnazar A.5, Asadi J.6 , Abedian Z.7, Borzouei- \\ sileh S. ${ }^{7,8}$
}

\begin{abstract}
Background: Diazinon is one of the most common pesticides in the world playing a similar role to radiation and it could cause DNA breaks and genetic effects.

Objective: In this study, radiosensitivity of a lymphoblastic cell line pretreated by Diazinon was investigated.
\end{abstract}

Material and Methods: In this case-control study, the human lymphoblastic T-cell line was divided into 6 groups based on receiving radiation or/and Diazinon. After that, the DNA damage, in all of the groups, were counted by cytokinesis-block micronuclei assay using different indices.

Results: The mean frequency of micronuclei, nuclear bridges and nuclear buds in cell groups exposed by both Diazinon and radiation were remarkably higher than the other groups which just received radiation or Diazinon alone. The interaction between radiation and Diazinon treatment was statistically significant for NBUDS index.

Conclusion: The results indicated that the Diazinon contamination could affect the radiosensitivity index of cancerous cells while further molecular and in-vivo studies are needed to investigate genetic and toxic effects of Diazinon on DNA and its repair system.

Citation: Ghasemi Sh, Shabestani Monfared A, Zabihi E, Khoshbin Khoshnazar A, Asadi J, Abedian Z, Borzoueisileh S. Changes in the Citation: Ghasemi Sh, Shabestani Monfared A, Zabihi E, Khoshbin Khoshnazar A, Asadi J, Abedian Z, Borzoueisileh S. Changes in the
Radiation Toxicity of Human Lymphoblastic T-cell Line (Jurkat) by a Common Pesticide: Diazinon. J Biomed Phys Eng. 2020;10(2):147-154. Radiation Toxicity of Human
doi: $10.31661 /$ jbpe.v0i0.715.

\section{Keywords}

Pesticides; Diazinon; Jurkat Cells; Radiotherapy; Radiation Tolerance

\section{Introduction}

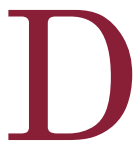
iazinon (O, O-diethyl-O-[2-isopropyl-6-methyl-4-pyrimidinyl] phosphorothioate), is an organophosphate pesticide which extensively is used in agriculture and household insect control [1]. Pesticides uses are aimed to control pests, weeds, and plant diseases. They cause chromosomal alteration and DNA damage and also are associated with various cancers [2]. One type of cancers that is in direct relevance with pesticides such as Diazinon use is Lymphoma (Hodgkin, non-Hodgkin and multiple myelomas), especially non-Hodgkin form [3].
${ }^{1} \mathrm{MSc}$, Student Research Committee, Babol University of Medical Sciences,

Babol, Iran

${ }^{2} \mathrm{PhD}$, Cancer Research

Center, Health Research

Institute, Babol Univer-

sity of Medical Sciences,

Babol, Iran

${ }^{3} \mathrm{PhD}$, Department of

Medical Physics Radio-

biology and Radiation

Protection, Faculty of

Medicine, Babol Univer-

sity of Medical Sciences,

Babol, Iran

${ }^{4} \mathrm{PhD}$, Cellular and Mo-

lecular Biology Research

Center, Health Research

Institute, Babol Univer-

sity of Medical Sciences,

Babol, Iran

${ }^{5} \mathrm{PhD}$, Faculty of Medicine.

Golestan University of

Medical Sciences, Gor-

gan, Iran

${ }^{6} \mathrm{PhD}$, Biochemistry and

Metabolic Disorders Re-

search Center, Golestan

University of Medical Sci-

ences, Gorgan, Iran

${ }^{7} \mathrm{PhD}$ Candidate, Cellular

and Molecular Biology

Research Center, Health

Research Institute, Babol

University of Medical Sci-

ences, Babol, Iran

${ }^{8} \mathrm{PhD}$ Candidate, Student

Research Committee,

Babol University of Medi-

cal Sciences, Babol, Iran

*Corresponding author: A. Shabestani Monfared Cancer Research Center, Babol University of Medical Sciences, Ganjafrooz

St., Babol, Iran

E-mail: monfared_ali@ yahoo.com

Received: 8 January 2017 Accepted: 14 April 2017 
The incidence in some types of lymphoma, in western countries, has been doubled during recent years [4] and Non-Hodgkin lymphoma is the sixth common cancer in Australia. There are still unknown factors which can cause malignant lymphoma, but there are a lot of risk factors such as immune deficiency, some specific infections and occupational exposures [5]. There are a lot of studies in the field of carcinogenesis of chemicals and pesticides [6].

The radiosensitivity, which is a biological response, is dissimilar in different patients [7]. Various factors such as tumor hypoxia, intrinsic radiosensitivity, expressing some genes like $\mathrm{p} 53$ and $\mathrm{Rb}$ are involved in sensitivity to radiation [7, 8]. Many efforts had been done to modify the radiosensitivity to decrease the total dose, fraction size or total time of treatment. Moreover, different techniques were examined to reduce the exposure to surrounding organs which may cause a reduction in tumor local control [9]. Some chemicals also were used as a radioprotector in this way to reduce the effect of radiation on normal cells [10-12]. It has been shown that high dose radiation in lymphoma treatment, in early stages, are involved with radiation toxicity, like dysphagia and mucositis [9].

DNA is the main target of radiation damage. Breakages in DNA cause apoptosis and other internal signals [13]. Cytokinesis-block micronucleus assay (CBMN) is a technique to monitor the genetic risks of exposures to radiation. Micronuclei (MN), Nuclear bridges (NPBs) and nuclear buds (NBUDs) are the indices to determine the intensity of lesions in cell lines [14]. Diazinon plays a similar role to radiation and it causes DNA breaks and creates genetic effects [15, 16]. Furthermore, It has shown that UV irradiation can magnify the effect of pesticides in Daphnia Magna [17, 18].

In this study, radiosensitivity of a lymphoblastic cell line pretreated by Diazinon was investigated to assess the effects of Diazinon contamination on DNA break counts and its association with radiosensitivity by using CBMN assay.

\section{Material and Methods}

In this case-control study, the human lymphoblastic T-cell line (Jurkat) was obtained from the Pasteur Institute of Iran. They were treated differently in 6 groups. A control group received neither radiation nor Diazinon, the second group is just irradiated with 2 Gy gamma radiation and group 3 received just $0.01 \mathrm{mg}$ / $\mathrm{ml}$ Diazinon without irradiation. Group 4 received $0.01 \mathrm{mg} / \mathrm{ml}$ Diazinon before 2 Gy radiation, group 5 received just $40 \mathrm{mg} / \mathrm{ml}$ Diazinon without radiation and finally Group 6 received $40 \mathrm{mg} / \mathrm{ml}$ Diazinon before 2 Gy radiation. The Jurkat cells were cultured in RPMI-1640 medium and complemented with $10 \%$ fetal bovine serum, penicillin-streptomycin (100 U/ $\mathrm{ml}$ penicillin, $100 \mu \mathrm{g} / \mathrm{ml}$ streptomycin), and 2 $\mathrm{mM}$ glutamine. Cells were grown at the $37^{\circ} \mathrm{C}$ incubator with $5 \% \mathrm{CO}_{2}$ in a humidified atmosphere. The medium was refreshed every two days.

\section{Treatment with Diazinon}

Cells were seeded at $2 \times 10^{5}$ cells $/ \mathrm{ml}$ in T-25 vented flasks and cell number was adjusted after incubating overnight in fresh medium to ensure the growth condition. To determine the DNA breaks induced by Diazinon, the cells were treated with $0,0.01$ and $40 \mu \mathrm{g} / \mathrm{ml}$ for 1 hour; next, the cells were washed once with RPMI-1640 and then with cell culture medium. After each washing, they were centrifuged at $2000 \times \mathrm{g}$ for 5 minutes, then the supernatant was discarded. Subsequently, the cells were resuspended in the medium and incubated for 4 hours.

\section{Irradiation}

We used a Coblat-60 source of a teletherapy (Theratron Phoenix) for 2 Gy gamma irradiation. The dose rate was $56.05 \mathrm{cGy} / \mathrm{min}$ and source-skin distance was $80 \mathrm{~cm}$. All of the cell lines underwent a transmission to the cell cul- 
ture laboratory for CBMN assay; irradiation of cells treated with Diazinon was done after 4 hours incubation.

\section{CBMN (cytokinesis-blocked micro- nuclei assay)}

After treatment with diazinon, irradiation process, and 4 hours incubation, CBMN assay was performed in all exposed, non-exposed and control groups. For this procedure, $6 \mu \mathrm{g} /$ $\mathrm{ml}$ cytochalasin B was added to each culture. After 28 hours, cells were harvested and then centrifuged for 5 minutes at $2000 \mathrm{rpm}$. The supernatant was discarded and fixed in $-20{ }^{\circ} \mathrm{C}$ methanol for $2 \mathrm{~h}$, then washed with Sorenson buffer and PBS for 5 minutes. Afterward, the cells were stained by $5 \%$ Giemsa (diluting 2.5 $\mathrm{ml}$ Giemsa in $47.5 \mathrm{ml} \mathrm{dH_{2 }} \mathrm{O}$, for 20 minutes) before dropping on slides. The slides were rinsed in $\mathrm{dH}_{2} \mathrm{O}$ and dried in air.

We observed the slides blindly, under a light microscope by $40 \times$ magnification. According to the suggestion of Fenech, all the micronuclei were scored in 1000 binucleated cells [19].
Besides the ratio of $\mathrm{MN}$, the NPBs and NUBDs were also scored in 1000 binucleated cells. The quantity of these two items in exposed to non-exposed cell groups was counted as others radiosensitivity indices. More micronuclei, bridges, and buds occur if a cell was more radiosensitive.

The one and two-way ANOVA and t-test were done between the different cell groups using the graph pad prism software, v6. The $p$ value under 0.05 was considered statistically significant and error bars represent the 95\% confidence interval. The study was approved by Babol University of Medical Sciences ethical committee.

\section{Results}

The averages of the MN frequency for the study groups were shown in Figure 1. The micronuclei frequency in cell groups exposed by both radiation and Diazinon is significantly higher than groups exposed just by radiation and Diazinon and control group. It is also implying that DNA breaks are associated with

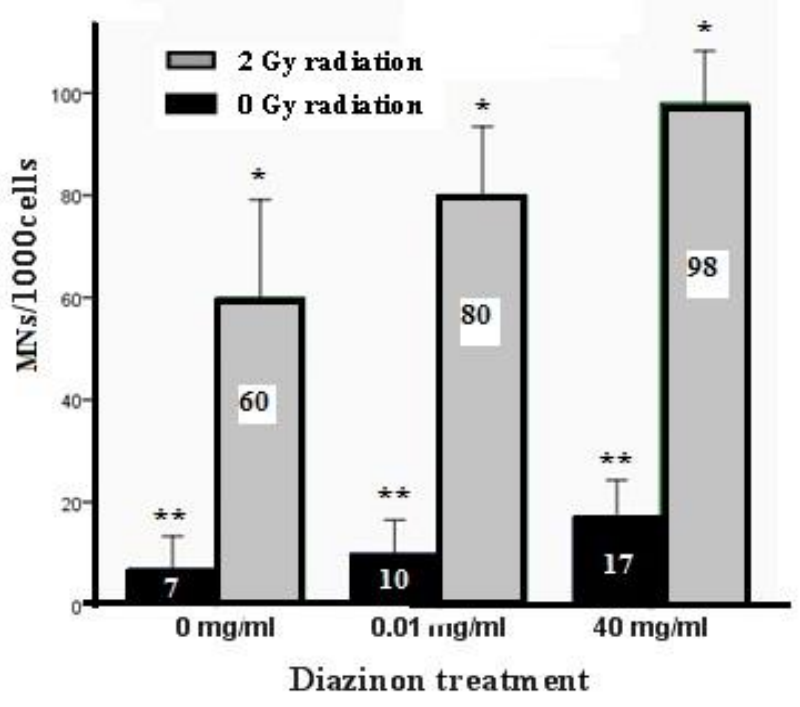

Figure 1: Micronuclei (MN) count in different situations, including different concentrations of Diazinon in the present of 0 and $2 \mathrm{~Gy}$ radiation. This figure shows the increase rate of $\mathrm{MN}$ after exposing to $2 \mathrm{~Gy}$ irradiation and increasing the Diazinon concentration. Error bars represent the $95 \%$ confidence interval. 
both radiation and Diazinon and also the rate of $\mathrm{MN}$ after exposing to radiation or Diazinon in all groups increased. However, it is more impressive in irradiated cells. As the Figure 1 showed, by increasing the Diazinon concentration, the rate of MNs will increase significantly.

DNA breaks and its misrepair, telomere and fusion lead to NPB and NBUDS. The frequency of NPB and NBUDS were shown in Figures 2 and 3. The overall behavior of them toward indices is alike with the $\mathrm{MN}$ index and they are associated with both radiation and $\mathrm{Di}$ azinon and the rate of them, after exposing to radiation or Diazinon in all groups, increased. As the Figures 2 and 3 showed, by increasing the Diazinon concentration and radiation dose, the rate of NPB and NBUDS will increase significantly.

As both the Figures 2 and 3 showed, the effects of two radiation and treatment with Di- azinon on NPB and NBUDS are significant but only the interaction between radiation and Diazinon treatment is significant for NBUDS index.

\section{Discussion}

The CBMN assay is a standard technique for evaluation of chemical materials and ionizing radiation effects on the DNA. In-vitro CBMN assay was used for measuring the differences in radiosensitivity and DNA damage in different studies [20-22]. In this assay, DNA damage could be scored by different indices, including micronuclei, nucleoplasmic bridges, and nuclear buds within binucleated cells [23]. NPBs and NBUDs are anomalies and reported as a biomarker of genotoxic events. CBMN assay is a way to measure the damage and can be used for inter-individual differences in radiosensitivity index [14].

Our data clearly indicate that the mean fre-

\begin{tabular}{|l|l|l|}
\hline & & \\
\hline Source of Variation & \% of total variation & P value \\
\hline Interaction & 0.7092 & 0.5446 \\
\hline Treatment Factor & 69.68 & $<0.0001$ \\
\hline Radiation Factor & 15.96 & $<0.0001$ \\
\hline
\end{tabular}

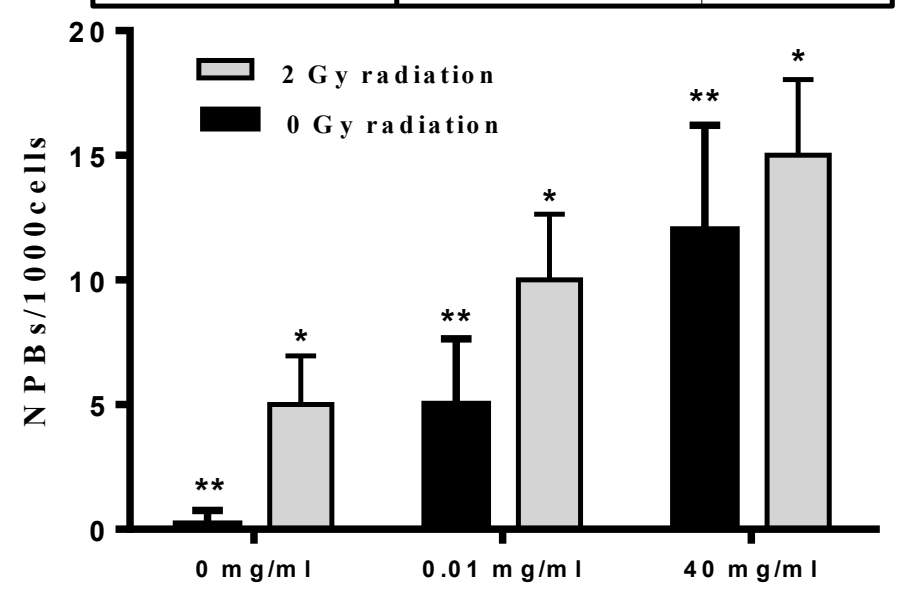

Diazinon treatment

Figure 2: Nuclear bridges (NPB) are counted in different situations, including different concentrations of Diazinon in the present of 0 and 2 Gy radiation. This figure shows the increase rate of NPB after exposing to $2 \mathrm{~Gy}$ irradiation and increasing the Diazinon concentration. Error bars represent the $95 \%$ confidence interval. 


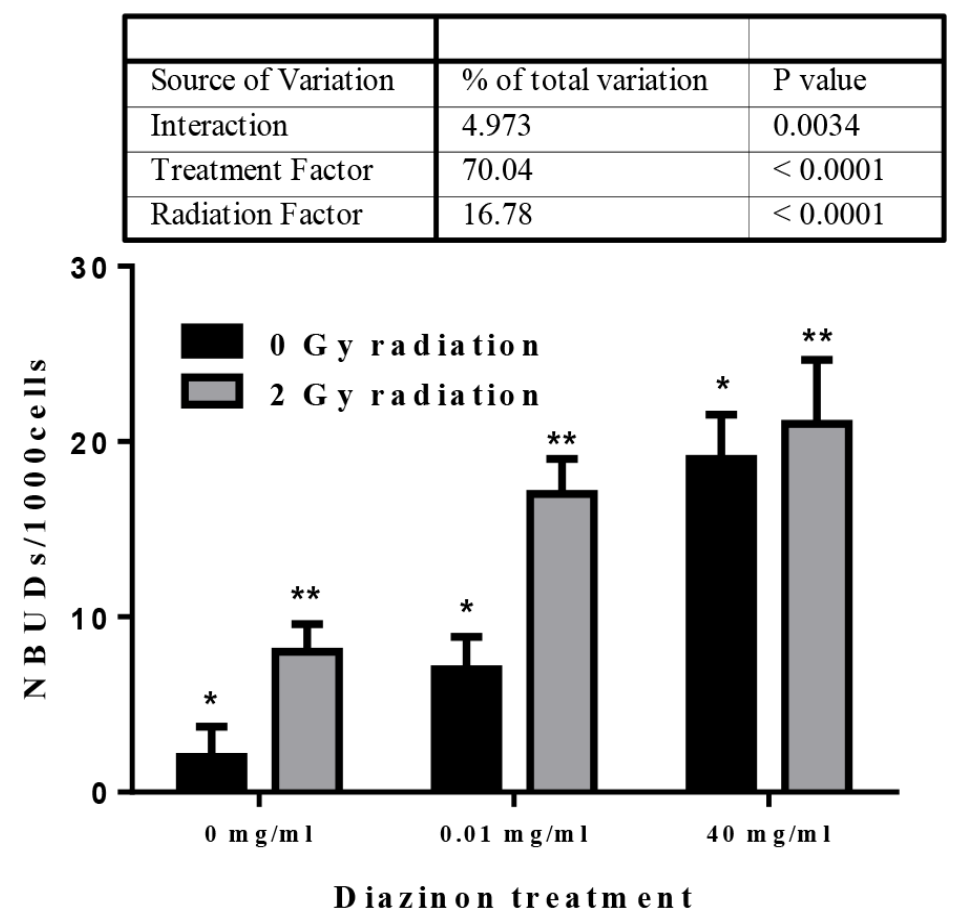

Figure 3: Nuclear buds (NBUD) are counted in different situations, including different concentrations of Diazinon in the present of 0 and $2 \mathrm{~Gy}$ radiation. This figure shows the increase rate of NPB after exposing to 2 Gy irradiation and increasing the Diazinon concentration. The interaction between radiation and Diazinon treatment is statistically significant. Error bars represent the $95 \%$ confidence interval.

quencies of NPBs and NBUDs in cell line groups exposed to both Diazinon and radiation are remarkably higher than the other groups receiving radiation or Diazinon, alone. The higher index of DNA damage in Diazinon group, as a pesticide, is in agreement with Adad et al. study, which showed that farmworkers who are often exposed to pesticides are at more risk of DNA damage and nuclear fragmentations [3]. There are some reports about the association between occupational exposure and chromosomal aberration which are somewhat different in magnitude $[2,24$, 25 ] and also the relation between some certain tumors and pesticides are reported [26]. Fritschi et al. have stated that workers dealing with pesticides such as Diazinon are at risk of lymphoma cancer especially non-Hodgkin [5]. The effects of radiation on CBMN assay scores were also proved by many studies [6].

Our data also showed that the mean fre- quency of $\mathrm{MN}$ in cell groups exposed by both Diazinon and radiation is remarkably higher than the other groups that just received radiation or Diazinon. Previous studies performed by Beketov et al. and Ribeiro et al. showed that some kinds of radiation like Ultraviolet can increase the sensitivity to radiation [17, 18]. Colovic et al. showed that incidence of micronuclei will increase by inducing more concentrations of Diazinon [27]. Zakerinia et al. reported that among different work categories, farmers are more exposed to different kinds of organophosphate or use and by this reason lymphoma malignancies especially non-Hodgkin form are more common in them [4]. But there are many other reports about the radioadaptive response after receiving an adaptive low dose which is not in agreement with our results [22, 28, 29]. Monfared et al. reported a radioadaptive response following thyroid scan [30] and some studies reported 
an adaptation to radiation after receiving low doses of other factors other than radiation.

In addition, the effects of both radiation and Diazinon on MN, NPB and NBUD were statistically significant; the interaction between radiation and Diazinon treatment was significant for NBUDS index. This may imply that for the patients with lymphoma cancer, which undergo radiation therapy, the presence of Diazinon may affect their radiosensitivity. The most important adverse effect of radiotherapy in these patients which appears during years after radiotherapy is the heart disease. The most important risk-increasing factor which is involved in this issue is the cumulative total radiation dose [31]. The prescribed dose of radiotherapy in malignancies is restricted by the tolerance of normal tissues [32]. The DNA of non-tumoral tissues receives radiation inevitably and it may lead to side effects. Some patients exhibit hypersensitivity to the standard dose of radiation and if we can predict the individual risk of adverse effect before radiation therapy, it would be a great benefit to optimize the treatment strategy.

There is no report dealing with the association of pesticides contamination and radiosensitivity until now [33]. Some results of the current study point to the probability of association between pesticides contamination and radiosensitivity and this study addresses needs for more in-vitro and in-vivo studies. Further molecular studies are needed to investigate more genetically and toxically effects of Diazinon on DNA and its repair system. If future research could prove our finding, history of contaminating with Diazinon could be used as a radiosensitivity index to revise the prescribing dose to lymphoma cancer patients and reduce the adverse effects of normal tissues against exposure to ionization radiation.

\section{Conclusion}

The effects of Diazinon and radiation on DNA damage and their interaction were investigated in the lymphoma cancer cell line.
Some results of the current study point to the probability of association between pesticides contamination and radiosensitivity and this study addresses the needs for more in-vitro and in-vivo studies.

\section{Acknowledgment}

This work is financially supported by the Vice Chancellor for Research and Technology, Babol University of Medical Sciences, Babol, Iran under Grant number 2004.

\section{Conflict of Interest}

None

\section{References}

1. Boussabbeh M, Ben Salem I, Hamdi M, Ben Fradj S, Abid-Essefi S, Bacha H. Diazinon, an organophosphate pesticide, induces oxidative stress and genotoxicity in cells deriving from large intestine. Environ Sci Pollut Res Int. 2016;23:2882-9. doi: 10.1007/s11356-015-5519-y. PubMed PMID: 26490884.

2. Bolognesi C. Genotoxicity of pesticides: a review of human biomonitoring studies. Mutat Res. 2003;543:251-72. PubMed PMID: 12787816. doi: 10.1016/s1383-5742(03)00015-2.

3. Adad LM, De Andrade HH, Kvitko K, Lehmann M, Cavalcante AA, Dihl RR. Occupational exposure of workers to pesticides: Toxicogenetics and susceptibility gene polymorphisms. Genet Mol Biol. 2015;38:308-15. doi: 10.1590/S1415475738320140336. PubMed PMID: 26500434. PubMed PMCID: PMC4612596.

4. Zakerinia M, Namdari M, Amirghofran S. The Relationship between Exposure to Pesticides and the Occurrence of Lymphoid Neoplasm. Iran Red Crescent Med J. 2012;14:337-44. PubMed PMID: 22924112. PubMed PMCID: PMC3420024.

5. Fritschi L, Benke G, Hughes AM, Kricker A, Turner $\mathrm{J}$, Vajdic CM, et al. Occupational exposure to pesticides and risk of non-Hodgkin's lymphoma. Am J Epidemiol. 2005;162:849-57. doi: 10.1093/aje/ kwi292. PubMed PMID: 16177143.

6. Khosravifarsani M, Monfared AS, Akhavan-Niaki $\mathrm{H}$, Moslemi D, Hajian-Tilaki K, Elahimanesh F, et al. The study of radiosensitivity in left handed compared to right handed healthy women. $B M C$ Med Phys. 2012;12:3. doi: 10.1186/1756-664912-3. PubMed PMID: 22920225. PubMed PMCID: PMC3531301. 
Effect of Diazinon on Radiosensitivity

7. Shabestani Monfared A, Borzoueisileh S, Zabihi E, Amiri M, Abedian S. Predicting factors of radiosensitivity in individual radiotherapy. Journal of Babol University of Medical Sciences. 2015;17:67-73.

8. Allison RR. Radiobiological modifiers in clinical radiation oncology: current reality and future potential. Future Oncol. 2014;10:2359-79. doi: 10.2217/fon.14.174. PubMed PMID: 25525845.

9. Yamashita M, Katayama N, Waki T, Katsui K, Himei K, Takemoto M, et al. Comparison of fieldin-field radiotherapy with conformal radiotherapy for unilateral cervical malignant lymphoma. Acta Med Okayama. 2015;69:189-95. doi: 10.18926/ AM0/53554. PubMed PMID: 26289909.

10. Samani F, Monfared AS, Zabihi E, Khafri S, Karimi $M$, Akhavan Niaki $H$. Evaluation of the effects of paederus beetle extract and gamma irradiation on HeLa cells. Iran J Basic Med Sci. 2014;17:3036. PubMed PMID: 24904724. PubMed PMCID: PMC4046238.

11. Nadi S, Monfared AS, Mozdarani H, Mahmodzade A, Pouramir M. Effects of Arbutin on Radiation-Induced Micronuclei in Mice Bone Marrow Cells and Its Definite Dose Reduction Factor. Iran J Med Sci. 2016;41:180-5. PubMed PMID: 27217601. PubMed PMCID: PMC4876295.

12. Heidari AH, Shabestani Monfared A, Mozdarani $\mathrm{H}$, Mahmoudzadeh A, Razzaghdoust A. Radioprotective Effects of Sulfur-containing Mineral Water of Ramsar Hot Spring with High Natural Background Radiation on Mouse Bone Marrow Cells. $J$ Biomed Phys Eng. 2017;7:347-54. PubMed PMID: 29445712. PubMed PMCID: PMC5809929.

13. Nowarski R, Wilner OI, Cheshin O, Shahar OD, Kenig $E$, Baraz $L$, et al. APOBEC3G enhances lymphoma cell radioresistance by promoting cytidine deaminase-dependent DNA repair. Blood. 2012;120:366-75. doi: 10.1182/ blood-2012-01-402123. PubMed PMID: 22645179. PubMed PMCID: PMC3398754.

14. Fenech M, Kirsch-Volders M, Natarajan AT, Surralles J, Crott JW, Parry J, et al. Molecular mechanisms of micronucleus, nucleoplasmic bridge and nuclear bud formation in mammalian and human cells. Mutagenesis. 2011;26:125-32. doi: 10.1093/ mutage/geq052. PubMed PMID: 21164193.

15. Muranli FD, Kanev M, Ozdemir K. Genotoxic effects of diazinon on human peripheral blood lymphocytes. Arh Hig Rada Toksikol. 2015;66:153-8. doi: 10.1515/aiht-2015-66-2584. PubMed PMID: 26110477.

16. Chiu BC, Dave BJ, Blair A, Gapstur SM, Zahm SH,
Weisenburger DD. Agricultural pesticide use and risk of $\mathrm{t}(14 ; 18)$-defined subtypes of non-Hodgkin lymphoma. Blood. 2006;108:1363-9. doi: 10.1182/blood-2005-12-008755. PubMed PMID: 16621961. PubMed PMCID: PMC1566872.

17. Beketov MA, Speranza A, Liess M. Ultraviolet radiation increases sensitivity to pesticides: synergistic effects on population growth rate of Daphnia magna at low concentrations. Bull Environ Contam Toxicol. 2011;87:231-7. doi: 10.1007/ s00128-011-0342-8. PubMed PMID: 21681397.

18. Ribeiro F, Ferreira NC, Ferreira A, Soares AM, Loureiro $S$. Is ultraviolet radiation a synergistic stressor in combined exposures? The case study of Daphnia magna exposure to UV and carbendazim. Aquat Toxicol. 2011;102:114-22. doi: 10.1016/j.aquatox.2011.01.007. PubMed PMID: 21333264.

19. Fenech M. The cytokinesis-block micronucleus technique: a detailed description of the method and its application to genotoxicity studies in human populations. Mutat Res. 1993;285:35-44. PubMed PMID: 7678131.

20. Elahimanesh F, Shabestani Monfared A, Khosravifarsani M, Akhavan Niaki $\mathrm{H}$, Abedian Z, HajianTilaki $K$, et al. Is Radiosensitivity Associated to Different Types of Blood Groups? (A cytogenetic study). Int J Mol Cell Med. 2013;2:131-5. PubMed PMID: 24551803. PubMed PMCID: PMC3920532.

21. Khosravifarsani M, Monfared AS, Akhavan-Niaki $H$, Moslemi D, Hajian-Tilaki K, Elahimanesh F, et al. The study of radiosensitivity in left handed compared to right handed healthy women. $B M C$ Med Phys. 2012;12:3. doi: 10.1186/1756-664912-3. PubMed PMID: 22920225. PubMed PMCID: PMC3531301.

22. Assadi N, Zabihi E, Khosravifarsani M, Khafri S, Akhavanniaki H, Amiri M, et al. Radioadaptive response in human lymphocyte cells. Int $\mathrm{J}$ Mol Cell Med. 2014;3:57-60. PubMed PMID: 24551822. PubMed PMCID: PMC3927389.

23. Georgellis A, Kolmodin-Hedman B, Kouretas D. Can traditional epidemiology detect cancer risks caused by occupational exposure to pesticides? J Exp Clin Cancer Res. 1999;18:159-66. PubMed PMID: 10464702.

24. Monfared AS, Mozdarani H, Amiri M. Natural background radiation induces cytogenetic radioadaptive response more effectively than occupational exposure in human peripheral blood lymphocytes. Czechoslovak Journal of Physics. 2003;53:A791-5.

25. Shabestani Monfared A, Mozdarani H, Samavat 
Ghasemi Sh., Shabestani Monfared A., Zabihi E. et al

$H$, Hashemoghli A. Chromosomal aberrations in radiation workers of radiology departments in Northern Iran-Babol. International Journal of Low Radiation. 2006;3:83-7. doi: 10.1504/ ijlr.2006.010011.

26. Thomas P, Fenech M. Cytokinesis-block micronucleus cytome assay in lymphocytes. DNA Damage Detection In Situ, Ex Vivo, and In Vivo. New York: Springer; 2011. p. 217-34.

27. Colovic M, Krstic D, Petrovic S, Leskovac A, Joksic G, Savic J, et al. Toxic effects of diazinon and its photodegradation products. Toxicol Lett. 2010;193:9-18. doi: 10.1016/j.toxlet.2009.11.022. PubMed PMID: 19948211.

28. Mortazavi S, Monfared A, Ghiassi-Nejad M, Mozdarani H. Radioadaptive responses induced in human lymphocytes of the inhabitants of high level natural radiation areas in Ramsar, Iran. Asian $J$ Exp Sci. 2005;19:19-31.

29. Borzoueisileh S, Shabestani Monfared A. Natural background radiations, radioadaptive response and radiation hormesis. Journal of Babol University of Medical Sciences. 2015;17:15-21.

30. Monfared A, Amiri M, Mozdarani H, Moazzezi Z. Can previous thyroid scan induce cytogenetic radio adaptive response in patients treated by radioiodine for hyperthyroidism? Iranian Journal of Radiation Research (Print). 2004:69-74.

31. Tuohinen S, Turpeinen A, Skytta T, KellokumpuLehtinen PL. Cardiac effects of radiation therapy. Duodecim. 2015;131:433-40. PubMed PMID: 26237905.

32. Moller P, Knudsen LE, Loft S, Wallin $H$. The comet assay as a rapid test in biomonitoring occupational exposure to DNA-damaging agents and effect of confounding factors. Cancer Epidemiol Biomarkers Prev. 2000;9:1005-15. PubMed PMID: 11045781.

33. Stone HB, Coleman CN, Anscher MS, McBride WH. Effects of radiation on normal tissue: consequences and mechanisms. Lancet Oncol. 2003;4:529-36. PubMed PMID: 12965273. 